\title{
SHIZOFRENIJA, STIGMA, SEKSUALNOST
}

\author{
Gorana Sulejmanpašić-Arslanagić, Nizama Tunović \\ Psihijatrijska klinika, Univerzitetski Klinički Centar Sarajevo \\ Bolnička 25, Sarajevo, Bosna i Hercegovina
}

Rad je primljen: 22.9.2015. Rad je revidiran: 19.10.2015. Rad je prihvaćen: 1.11.2015.

\section{SAŽETAK}

Shizofrenija je ozbiljni psihički poremećaj, karakteriziran pozitivnim simptomima (halucinacije, sumanute ideje i formalni poremećaj mišljenja), negativnim simptomima (socijalna izolacija i afektivna tupost). Stigma je uzrokovana kombinacijom ljudskog neznanja i straha, stvaranjem ukorijenjenih mitova i predrasuda. Seksualnost je kod osoba sa shizofrenijom uvijek bila zanemarivana tema kako sa aspekta istraživanja tako i u kliničkoj praksi. Antipsihotici se vežu na nekoliko centralnih i perifernih receptorskih sistema što rezultira razvojem profila djelotvornosti, ali isto tako dovodi i do pojave neželjenih efekata Navedeno djelovanje je multifaktorsko, uključujući promjene na nivou prolaktina i antagonizma alfa adrenergičkih, dopaminergičkih, histaminskih i muskarinskih receptora, odnoseći se na jedno ili više od tri područja ciklusa seksualnog odgovora: libido, vaginalna lubrikacija ili erektilna disfunkcija i orgazam. Problem seksualnosti kod pacijenata sa shizofrenijom je kompleksna, ali njihove potrebe i želje su umanjene u tradicionalnoj psihijatrijskoj praksi, a njihova zabrinutost zbog seksualne diskunkcije može pogoršati simptome bolesti. Planiranje porodice, edukacija i savjetovanje treba biti sastavni dio sveobuhvatog plana u okviru brige ove vulnerabilne populacije. Potreba za što adekvatnijim pristupom duševno oboljelim osobama i poboljšavanju dijagnostičko-terapijskog postupka je konstantna.

Ključne riječi: shizofrenija, stigma, seksualnost

Korespodencija:

Dr sci med Gorana Sulejmanpašić-Arslanagić

Psihijatrijska klinika, UKC Sarajevo, Bolnička 25

033/297-538,e-mail:sretnidjecak@gmail.com

\section{UVOD}

Shizofrenija, kao psihopatološki entitet, u okviru psihijatrijskih istraživačkih programa dobila je status najatraktivnije teme. Shizofrene manifestacije u pogledu sadržaja, pokazuju bogatstvo individualnih razlika, zadržavajući stabilne obrasce vezane za nastanak, manifestovanje i tok bolesti. U slučaju eksplanacije shizofrene psihoze jedinu vrijednost imaju etiološki modeli koji uvažavaju i endogeno i egzogeno, pretpostavljajući njihovu komplementarnost. Nijedna bolest ne razara tako radikalno ličnost i temelje ljudskog bića kao što to čini shizofrenija (1). Shizofrenija je ozbiljni psihički poremećaj, karakteriziran pozitivnim simptomima (halucinacije, sumanute ideje i formalni poremećaj mišljenja), negativnim simptomima (socijalna izolacija i afektivna tupost). Čuveni opisi mentalnih poremećaja naslijeđeni iz perioda Kraepelina, Bleulera i drugih poznatih teoretičara s kraja 19. i početka 20 . vijeka, iznenađuju svojom jednodimenzionalnošću i naivnošću postuliranih modela objašnjenja. Otkako je prije sto godina Eugen Bleuler (1911) preimenovao Kraepelinovu dementia-u praecox $u$ shizofreniju, ova heterogena grupa poremećaja predmet je brojnih i multidisciplinarnih naučnih istraživanja i filozofskih razmatranja. Naziv shizofrenija potiče od Eugena Bleulera, koji je prvi upotrijebio ovaj termin 1911. godine za bolest koja je do tada bila poznata pod nazivom dementia praecox. Međutim, Emilu Kraepelinu pripisuje se zasluga za nozološko određenje ove bolesti 1896. godine, jer je prvi uočio šta je zajedničko u nizu raznovrsnih psihopatoloških ispoljavanja i kliničkih slika katatone, hebefrene i paranoidne dementiae praecox. Sam termin dementia praecox datira od 1851. godine kada je Morel u 
svojim „Kliničkim studijama“ njime označio poremećaj koji počinje vrlo rano, još u adolescenciji, a dovodi do intelektualnog propadanja. E.Hecker je 1871. godine pod nazivom hebephrenia opisao sindrom intelektualnog propadanja $\mathrm{u}$ mladih osoba s fazama promjenjivog raspoloženja, dok je 1874 . godine Kahlbaum opisao katatoniju. Prema nekim teorijama, shizofrenija je bila nepoznata prije 1750 . godine, a „epidemija ludosti“ započela je oko 1780. godine i stabilizirala se oko 1900. godine (2).

\section{STIGMA}

Nažalost, svjesni smo svakodnevne diskriminacije duševno oboljelih osoba kroz prizmu neznanja društvene zajednice o bolestima ljudske duše, smatrajući ih nasilnima, nesposobnima, neodgovornima, nepredvidivima, lijenima, krivima za bolest. Stigmatizacija je povezana sa predrasudama, negativnim konotacijama da se duševna bolest ne može liječiti. Značenje riječi stigma potiče od grčke imenice naglasiti, istaknuti, označiti i u Novom zavjetu i ranom kršćanstvu je povezano s Kristovim ranama. Latinsko objašnjenje predstavlja $\mathrm{u}$ metaforičkom smislu sram ili degradaciju, sa negativnim obilježavanjem osobe samo zato što ima dijagnozu psihičke bolesti, a najčešće se to odnosi na shizofreniju. Stigma je uzrokovana kombinacijom ljudskog neznanja i straha, stvaranjem ukorijenjenih mitova i predrasuda, a shizofrenija je, kao bolest, ostala za javnost jedno od rijetkih medicinskih područja uz čiji se spomen vezuje osjećaj nelagode, straha, predrasuda i izbjegavajućeg ponašanja (3). Kombinacija teške psihičke bolesti, diskriminacije i stigmatiziranosti je pogubna za psihičke bolesnike i kroz istoriju je igrala veliku ulogu u njihovoj emocionalnoj i socijalnoj izoliranosti, što vodi produbljivanju njihovih patnji. Posljedica stigme je diskriminacija koja spada u tešku povredu osnovnih ljudskih prava. Navedeno interferira sa percepcijama međuljudskih odnosa, verbalnom i neverbalnom komunikacijom, što dovodi do udaljavanja bolesnika od porodice i prijatelja (4). Sprovođenje antistigma programa kroz edukaciju šire društvene zajednice o psihičkim bolestima, otvoreni razgovori i rasprave o razbijanju strahova spram oboljelih, kao i značajna uloga medija u razbijanju mitova, može i treba umanjiti patnje koje pacijenti proživljavaju (5).

\section{SEKSUALNOST I ANTIPSIHOTICI}

Sama bolest i postojanje negativnih simptoma (avolicija, anhedonija i socijalna izoliranost), oštećuje socijalne kapacitete i narušava interpersonalne interakcije duševno oboljelih. Ukupna efiksnost je narušena sa umanjenim kapacitetom sposobnosti izražavanja emocija što utiče i na normalnu seksualnu ekspresiju, emotivne veze, seksualnost, te libido. Bolest sama po sebi utiče i na normalno izražavanje seksualnih razmišljanja

Seksualnost je kod osoba sa shizofrenijom uvijek bila zanemarivana tema kako sa aspekta istraživanja tako i u kliničkoj praksi. Suprotno vladajućim sterotipima, osobe oboljele od shizofrenije mogu biti uključene u zdravu seksualnu aktivnost. Problem seksualnosti kod pacijenata sa shizofrenijom je kompleksna, ali njihove potrebe i želje su umanjene u tradicionalnoj psihijatrijskoj praksi. Rasprava o seksualnosti treba da bude prirodna u okviru pacijentovih iskustava kao i kod svakog ljudskog bića. Naravno, postoje i socijalne barijere koje interferiraju sa evidentiranjem seksualne disfunkcije koje djeluju čak i na zdravstvene radnike (6).

Primjena antipsihotika je neizostavna u tretmanu bolesti sa aspekta opšte funkcionalnosti individue, ali njihova upotreba takođe dovodi do razvoja seksualne disfunkcije (7). Antipsihotici se vežu na nekoliko centralnih i perifernih receptorskih sistema što rezultira razvojem profila djelotvornosti, ali isto tako dovodi i do pojave neželjenih efekata. Seksualna difunkcija izazvana primjenom antipsihotika može biti posredovana putem nekoliko mehanizama: centralni nespecifični efekti (sedacija), centralni specifični efekti, periferni efekti i hormonalni. Navedeno djelovanje je multifaktorsko, uključujući promjene na nivou prolaktina i antagonizma alfa adrenergičkih, dopaminergičkih, histaminskih i muskarinskih receptora, odnoseći se na jedno ili više od tri područja ciklusa seksualnog odgovora: libido, vaginalna lubrikacija ili erektilna disfunkcija i orgazam (8). 
Tabelarni prikaz ciklusa seksualnog odgovora:prolaktin/antagonizam receptora

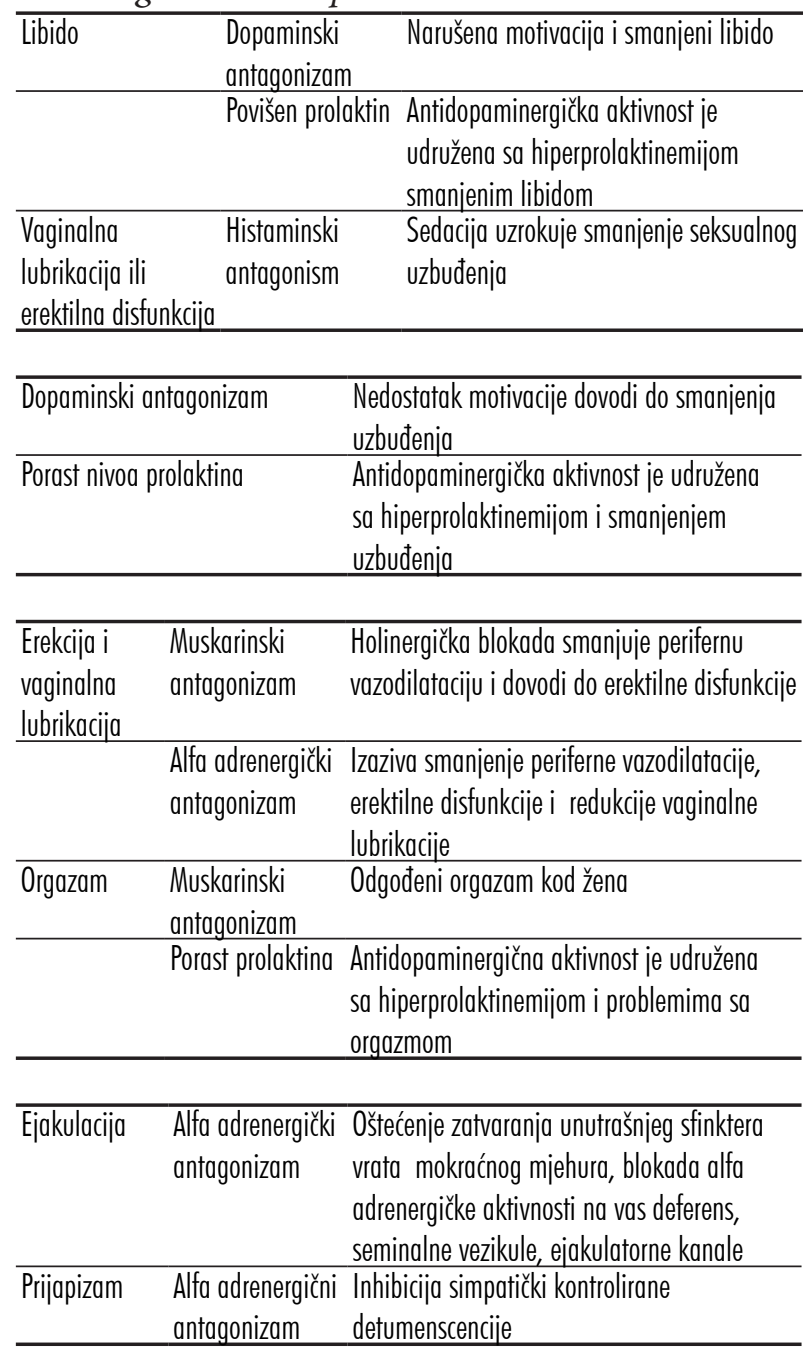

Većina atipičnih neuroleptika je neselektivna i djeluje na više centralnih i perifernih receptora. Dopaminergična blokada može imati direktno djelovanje u smislu narušavanja motivacije (seksualna želja) i postizanja orgazma, te indirektno negativan uticaj na seksualnost. Blokirajuće i/ili modulirajuće djelovanje atipičnih neuroleptika na adrenalinske, serotoninske, histaminske ili acetilholinske receptore može doprinijeti pojavi sekundarnih seksualnih problema (9). Farmakološki profil nekih neuroleptika je karakteriziran jakim afinitetom za D2 i alfa1 receptore, što korelira sa tendencom značajnog podizanja nivoa prolaktina stvarajući problem sa ejakulacijom. Odgođena ejakulacija može biti povezana sa jakom adrenolitičkom aktivnosti neuroleptične terapije. Sekundarno izazvana hiperprolaktinemija primjenom antipsihotika je dozno ovisna, rezultirajući mogućim razvojem hipogonadizma, više izražena kod ženskih pacijenata, sa štetnim uticajem na seksualnu funkciju. Dugoročne posljedice sekundarnog hipogonadizma su predmet mnogih rasprava (10). Primjena antipsihotika može dovesti do pojave galaktoreje i amenoreje, i može se javiti kod oko 30\% žena u premenopauzi. Kada je hiperprolaktinemija simptomatska, smanjenje doze antipsihotika ili njegova promjena je preporučljiva. Žene sa sekundarno izazvanom amenorejom i hiperprolaktinemijom usljed primjene antipishotika trebaju biti savjetovane da se primjenom gore navedenih postupaka menstrualni ciklus može ponovno uspostaviti (11).

\section{ZAKLJUČAK}

Shizofrena psihoza se manifestira iskrivljenim doživljavanjem i percepcijom života i svijeta oko sebe pa i sebe samoga, iskrivljenom hijerarhijom doživljenoga, poremećenim tokom mišljenja i njegovim sadržajem, a vjerovatno u vezi s tim i poremećajem afektivnog života i asocijacija. Sve to često dovodi do smetenosti, košmara, rasplinutosti, specifičnog intelektualnog propadanja, infantilnosti, bizarnosti i gotovo uvijek do ozbiljnog poremećaja funkcioniranja. Psihički oboljele osobe se često i neopravdano doživljavaju kao socijalno opasne, nesposobne i neodgovorne, te ih okolina izolira, pretvara u beskućnike i uvodi u ekonomsko propadanje. Smanjuju se mogućnosti za normalan život, rad, liječenje, rehabilitaciju i povratak u društvenu zajednicu, a i oni sami se osjećaju neshvaćenima, usamljenima. Problem seksualnosti kod pacijenata sa shizofrenijom je kompleksna, a njihova zabrinutost zbog seksualne diskunkcije može pogoršati simptome bolesti. Planiranje porodice, edukacija i savjetovanje treba biti sastavni dio sveobuhvatog plana u okviru brige ove vulnerabilne populacije. Potreba za što adekvatnijim pristupom duševno oboljelim osobama i poboljšavanju dijagnostičko-terapijskog postupka je konstantna. O zajedničkim bolestima duše nezahvalno je govoriti s obzirom na složenost poremećaja i sve njegove uzroke rasijane po lavirintima ljudske duše. 


\section{LITERATURA}

1. Richardson-Andrews RC. The suspot theory of schizophrenia: further evidence, a change of mechanism, and a strategy for the elimination of the disorder. Med Hypotheses 2009;72:95-98.

2. Read J. A history of madness. U: Read J,Mosher LR\&Bentall RP (ur): Models of Madness-Psychological, Social and Biological Approaches to Schizophrenia. Brunner-Routledge 2004;9-20.

3. Kommana S, Mansfeld M. Dispelling the stigma of schizophrenia. Psychiatric Services 1997; 48:1393-1395.

4. Phelan JC, Link BG. Psychiatric illness and family stigma. Schizophrenia Bulltin 1998;24:115126.

5. Tartakovsky M. Illuminating 13 Myths of Schizophrenia. Psych Central. 2013.

6. Macdonald S, Halliday J, MacEwan T. et al. Nithsdale Schizophrenia Surveys 24: sexual dysfunction. Case-control study. Br J Psychiatry 2003;182:50-56.
7. Cutler AJ. Sexual dysfunction and antipsychotic treatment. Psychoneuroendocrinology 2003;28:69-82.

8. Hummer M, Huber J. Hyperprolactinaemia and antipsychotic therapy in schizophrenia [review]. Curr Med Res Opin 2004;20:189-97.

9. Richelson E, Souder T. Binding of antipsychotic drugs to human brain receptors focus on newer generation compounds. Life Sciences 2000;68:29-39.

10. Baptista T, Reyes D, Hernandez L. Antipsychotic drugs and reproductive hormones: Relationship to body weight regulation. Pharmacology, Biochemistry, and Behavior 1999;62:409-17.

11. Lambert M, Conus P, Eide P, et al. Impact of present and past antipsychotic side effects on attitude toward typical antipsychotic treatment and adherence. Eur Psychiatry 2004;19 415-422. 


\title{
SCHIZOPHRENIA, STIGMA, SEXUALITY
}

\author{
Gorana Sulejmanpašić-Arslanagić, Nizama Tunović \\ Psychiatric Clinic, Clinical Center University of Sarajevo \\ 25 Bolnička, Sarajevo, Bosnia and Herzegovina
}

\begin{abstract}
Schizophrenia is a mental disorder characterized by positive symptoms (hallucinations, delusions and formal personality disorders) and negative symptoms (social isolation and affective dullness). Stigma is caused by a combination of human ignorance and fear, by creation of rooted myths and prejudice. Sexuality in persons with schizophrenia was always a neglected topic, both in research and clinical practice. Antipsychotic drugs are linked to several central and peripheral receptor systems which results in the development of the efficacy profile, but leads to undesired side effects. The specified action is multifactor, and it includes changes in the levels of prolactin and antagonisms; alpha adrenergic, dopaminergic, histamine and muscarinic receptors, which refer to one or more than three cycles of sexual response: libido, vaginal lubrication or erectile dysfunction, and orgasm. The problem of sexuality in patients with schizophrenia is a complex matter, but their needs and desires are decreased in traditional psychiatric practice, while their concern over sexual dysfunction may worsen the symptom of the disorder. Family planning, education and counseling should be an integral part of comprehensive plan in the care of this vulnerable population. The need for an adequate approach to mentally ill persons and an improvement of diagnostic and therapeutic procedure is constant.
\end{abstract}

Key words: schizophrenia, stigma, sexuality

Correspondence:

Gorana Sulejmanpašić-Arslanagić, $\mathrm{MD}, \mathrm{PhD}$

Psychiatric Clinic, Clinical Center University of Sarajevo, 25 Bolnička

033/279-538

E-mail: sretnidjecak@gmail.com 